\title{
The effect of grazing on the composition of conjugated linoleic acid isomers and other fatty acids of milk and cheese in goats*
}

\author{
F. Pajor ${ }^{1,3}$, O. Galló ${ }^{1}$, O. Steiber ${ }^{1}$, J. Tasi ${ }^{2}$ and P. Póti ${ }^{1}$ \\ Szent István University, \\ ${ }^{1}$ Institute of Animal Husbandry, \\ ${ }^{2}$ Institute of Crop Production \\ Páter Károly 1, H-2103, Gödöllö, Hungary
}

(Received 10 December 2008; revised version 19 February 2009; accepted 24 June 2009)

\begin{abstract}
The effect of grazing on the fatty acid profile of milk and cheese was evaluated on 20 goats divided into two groups. The goats in the first group were kept indoors and fed with lucerne hay, the goats from the second group were kept on a natural pasture. Utilization of native pasture has been on a low level (extensive) for years in order to avoid over-grazing of the grassland. The milk from grazed goats had significantly higher contents of fat, protein and total solids without fat $(\mathrm{P}<0.001)$ as well as lower lactose content than goats kept indoors $(\mathrm{P}<0.01)$. Grazing considerably increased the total conjugated linoleic acid content in milk $(0.59$ vs $0.77 \% ; \mathrm{P}<0.001)$ and cheese $(0.52$ vs $0.84 \%$; $\mathrm{P}<0.01)$. The distribution of $n-3$ and $n-6$ was much better in the grazed goats, i.e. the values of series $\mathrm{n}-3$ fatty acids were higher in milk $(0.52$ vs $0.69 \% ; \mathrm{P}<0.01)$ and cheese $(0.64$ vs $1.07 \% ; \mathrm{P}<0.01)$. In addition, the $\mathrm{n}-6 / \mathrm{n}-3$ ratio was also more favourable in the grazed group (milk: 6.10 vs 3.44 ; cheese: 4.19 vs $2.51 ; \mathrm{P}<0.01$ ). It is concluded that the milk and cheese from goats kept on the natural pasture were better in terms of nutraceutical parameters, which are advantageous in human nutrition, than the milk produced by animals kept indoors and fed with hay.
\end{abstract}

KEY WORDS: goat, grazing, milk, cheese, fatty acids

\section{INTRODUCTION}

In recent years there has been increased interest in how to manipulate the fatty

\footnotetext{
* Supported by Baross, Project OMFB-01174/2006

${ }^{3}$ Corresponding author: e-mail: Pajor.Ferenc@mkk.szie.hu
} 
acid composition of foods. High saturated fatty acid intake leads to coronary heart disease (CHD), which is one of the most common causes of mortality in Europe. Nutritionists have focused on the type of polyunsaturated fatty acids (PUFA) and the balance in the diet between n-3 PUFA formed from $\alpha$-linolenic acid (C18:3) and n-6 PUFA formed from linoleic acid (C18:2) (Williams, 2000). The typical Western diet is characterized by a high intake of n-6 PUFA and a low intake of n-3 PUFA. A high ratio of n-6/n-3 PUFA is a risk factor in cancers and coronary heart disease, especially formation of blood clots leading to a heart attack (Enser et al., 1998). It is recommended that the ratio of $n-6 / n-3$ be less than 4 (Wood et al., 2003).

The conjugated linoleic acid, $c 9 t 11 \mathrm{CLA} \mathrm{C}_{18: 2}$, has been demonstrated to have a range of positive health effects. c9t11CLA suppresses carcinogenesis (Belury, 1995), modulates the immune system (Cook et al., 1993), and reduces atherogenesis (Nicolasi et al., 1997). c9t11CLA is produced in the rumen by anaerobic bacteria as an intermediate in the biohydrogenation of linoleic acid and by desaturation of vaccenic acid $\left(t 11 \mathrm{C}_{18: 1}\right)$ in the mammary gland via $\Delta 9$-desaturase (Bauman et al., 2001, cited in Tsiplakou et al., 2006).

Changing of food composition has given way to a growing area in food technology; this new area is the "functional foods". Functional foods have been defined as foods having the presence of physiologically active components (c9t11CLA, n-3 fatty acids) that provide a health benefit beyond basic nutrition (Hasler, 2000). Functional foods and innovative cheese products may be able to help in developing the goat sector in Hungary and the European Union.

The number of studies on the effects of pasture and other diet compositions on fatty acids, especially on CLA isomer composition and on its precursors, is rather limited in goat milk (Tsiplakou et al., 2006; Czauderna et al., 2007) and cheese (Galina et al., 2007), compared with cows.

The aim of this study was to investigate the effect of extensive grazing of a natural pasture on the conjugated linoleic isomer and n-3 fatty acid contents of goat milk and cheese.

\section{MATERIAL AND METHODS}

\section{Experimental animals}

The study was carried out in typical lowland (Great Plane) on a goat farm (Bösztör, Bács-Kiskun County, Hungary). Twenty Hungarian Improved goats (average days in milk $=20$ ) were divided to two groups. The goats from one group were kept indoors and fed with lucerne hay $(n=10)$, the goats from the other group 
were kept on a natural pasture $(\mathrm{n}=10)$. The groups were balanced for parity and time of kidding. The health and nutritional status of the animals were good during the experimental period.

Grazing (and, consequently, this experiment) started in mid-April. The grazed group stayed all day long on the pasture; however, they were fed with 300$400 \mathrm{~g} /$ day grain mix (\%: barley 40, wheat 20, maize 20 and wheat bran 20) as a supplementary feed. The control animals received ad libitum lucerne hay (approximately $2 \mathrm{~kg}$ /day) and 300-400 g/day grain mix (\%: barley 40, wheat 20, maize 20 and wheat bran 20). Both groups had the same composition of the grain mix, which was given twice a day in equal amounts. The experimental period lasted 5 weeks, which involved the period of the first 3 weeks for adaptation to the diet and the last 2 weeks for milk collection. The goats were milked twice a day at 06.00 a.m. and 18.00 p.m., in addition individual milk samples were collected once a week during the last 2 weeks of the experimental period. The samples of the grass, lucerne hay and grain mix were gathered on the last week. The main components of the fed forages are given in Table 1, and composition of the essential fatty acids in the forages is shown in Table 2.

Table 1. Chemical composition of feeds

\begin{tabular}{lcrcc}
\hline \multirow{2}{*}{ Component } & \multirow{2}{*}{ Unit } & Grass & Lucerne hay & Grain mix \\
\cline { 3 - 5 } & & & $\mathrm{n}=3$ & \\
\hline Dry matter (DM) & $\mathrm{g} / \mathrm{kg}$ feed & 280.0 & 911.2 & 891.6 \\
Crude protein & $\mathrm{g} / \mathrm{kg} \mathrm{DM}$ & 115.6 & 149.7 & 137.3 \\
Crude fat & $\mathrm{g} / \mathrm{kg} \mathrm{DM}$ & 27.2 & 17.0 & 33.2 \\
Crude fibre & $\mathrm{g} / \mathrm{kg} \mathrm{DM}$ & 285.2 & 330.6 & 37.6 \\
Crude ash & $\mathrm{g} / \mathrm{kg} \mathrm{DM}$ & 79.6 & 83.4 & 41.9 \\
$\mathrm{~N}-$ free extractives $_{\mathrm{NE}}$ & $\mathrm{g} / \mathrm{kg} \mathrm{DM}$ & 495.1 & 419.3 & 750.0 \\
$\mathrm{NE}_{\mathrm{l}}$ & $\mathrm{MJ} / \mathrm{kg} \mathrm{DM}$ & 4.55 & 4.30 & 8.94 \\
& $\mathrm{MJ} / \mathrm{kg} \mathrm{DM}$ & 4.61 & 3.90 & 8.36 \\
\hline
\end{tabular}

Utilization of native pasture is extensive in order to avoid over-grazing of the grassland. Forty-nine plant species were identified on the natural pasture. The plant cover averaged 94\%. The main species were Festuca pseudovina, Cynodon dactylon, and the main legume was Lotus corniculatus. The grass yield (green) was $1.13 \mathrm{t} / \mathrm{ha}$ in May (and average annual 3.2 $\mathrm{t} / \mathrm{ha}$ green yield). The stocking density of the pastures grazed by the goat was about $0.5 \mathrm{AU} / \mathrm{ha}$. The average annual rainfall of the area is approx. $450 \mathrm{~mm}$. During the daily routine the grazed goats were driven to pasture after the morning milking, and collected in the afternoon to be milked and confined for the entire night. The other group was kept indoors in full confinement during the study. 
Table 2. Fatty acid composition of feeds, $\%$

\begin{tabular}{lrcr}
\hline Fatty acids & Grass & Lucerne hay & Grain mix \\
\cline { 2 - 4 } C12:0 & & $\mathrm{n}=3$ & \\
C14:0 & 1.33 & 1.41 & 0.02 \\
C14:1 & 1.50 & 1.01 & 0.13 \\
C16:0 & 0.15 & 0.08 & 0.02 \\
C16:1 & 20.77 & 27.79 & 14.73 \\
C18:0 & 1.64 & 1.6 & 0.14 \\
C18:1n-9 & 2.60 & 4.59 & 1.96 \\
C18:2n-6 & 4.58 & 4.45 & 21.69 \\
C18:3n-3 & 17.37 & 20.68 & 56.01 \\
C20:0 & 39.56 & 26.96 & 3.40 \\
& 3.17 & 2.24 & 0.37 \\
\hline
\end{tabular}

\section{Cheese manufacturing}

In the study, two different kinds of cheese were produced by home and feeding technologies. Milk samples were collected 3 independent times from the different dietary treatments $(1+2$ samples in first and second weeks of the experimental period). The milk of each group was processed into cheese. The goat semi-hard cheese was made by the process shown in Table 3 . The cheese samples were collected after the 4-week-ripening period.

Table 3. Description of cheese production

\begin{tabular}{lc}
\hline Description & Characteristic of manufacturing \\
\hline Pasteurizing & $63-65^{\circ} \mathrm{C}, 30$ min, cooling to $40^{\circ} \mathrm{C}$ \\
Addition bacterial culture and $\mathrm{CaCl}_{2}$ & PROBAT 222 \\
Addition commercial rennet & Chy-Max rennet \\
Scooping and draining & wheat size \\
Post heating & up to $38^{\circ} \mathrm{C}$ \\
Formatting to moulding & $1.5-2 \mathrm{~kg}$ \\
Press & half day \\
Salt bath & $1.5-2$ days \\
Ripen & $17-18^{\circ} \mathrm{C}, 85 \%$ relative humidity for 4 weeks \\
\hline
\end{tabular}

\section{Chemical analysis}

The forage samples were analysed for dry matter, crude protein, crude fat, crude fibre and crude ash according to the procedure of Hungarian Feed Codex (1990).

Fat, protein, lactose and total solids without fat contents of milk were determined using a MilkoScan device (Combi Foss 5000 apparatus, Foss Electric). The milk and cheese fat were dissolved in sodium hydroxide methanol solution and re-esterified to methyl-esters according to the AOAC (1990) method using boron trifluoride $\left(\mathrm{BF}_{3}\right)$. Methyl esters of fatty acids were determined by gas 
chromatography using a Shimadzu GC 2010 apparatus (Japan). Parameters of the chromatographic determination are given in Table 4.

Table 4. Parameters of chromatographic analysis of fatty acids

\begin{tabular}{ll}
\hline Parameter & \multicolumn{1}{c}{ Value } \\
\hline Column & CP-SIL-88 $(100 \mathrm{~m} \times 0.25 \mathrm{~mm} \times 0.2 \mu \mathrm{m})$ \\
Detector & FID \\
Split ratio & $1: 50$ \\
Temperature & $80^{\circ} \mathrm{C}$ for 0 min \\
$\quad$ column & $2.5^{\circ} \mathrm{C} / \mathrm{min}$ up to $205^{\circ} \mathrm{C}$, held for $20 \mathrm{~min}$ \\
& $10^{\circ} \mathrm{C} / \mathrm{min}$ up to $225^{\circ} \mathrm{C}$, held for $5 \mathrm{~min}$ \\
$\quad$ injector & $270^{\circ} \mathrm{C}$ \\
$\quad$ detector & $300^{\circ} \mathrm{C}$ \\
Helium flow & $28 \mathrm{~cm} / \mathrm{s}$ \\
Injection & $0.5 \mu 1$ \\
\hline
\end{tabular}

Peaks were identified on the basis of the retention times of standard methyl esters of individual fatty acids (Mixture Me 100, Larodan Fine Chemicals AB, Sweden). The proportions of the individual acids were calculated by the ratio of their peak area to the total area of all observed acids.

\section{Statistical analysis}

Data were analysed using the SPSS 14.0 statistical program package (F- test, T- and Welch's corrected T-test).

\section{RESULTS}

The milk from grazed goats had significantly higher $(\mathrm{P}<0.001)$ fat, protein and total solids contents and considerably lower $(\mathrm{P}<0.01)$ lactose content than the milk produced by the animals kept indoors (Table 5).

Table 5. Composition of goat milk from different feeding technologies

\begin{tabular}{lccccccc}
\hline \multirow{2}{*}{ Milk composition, \% } & \multicolumn{2}{l}{ Indoor group $(\mathrm{n}=10)$} & & \multicolumn{2}{c}{ Grazed group $(\mathrm{n}=10)$} & \multirow{2}{*}{$\mathrm{P}$} \\
\cline { 2 - 3 } \cline { 5 - 6 } & mean & $\mathrm{SD}$ & & mean & $\mathrm{SD}$ & \\
\hline Fat & 2.96 & 0.13 & & 3.62 & 0.16 & \multirow{2}{*}{ *** } \\
Protein & 2.90 & 0.04 & & 3.18 & 0.08 & $* * *$ \\
Lactose & 4.64 & 0.04 & & 4.48 & 0.15 & $* *$ \\
Total solids without fat & 7.72 & 0.15 & & 8.05 & 0.13 & *** \\
\hline
\end{tabular}

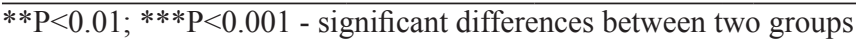


Results of the fatty acid analysis of the milk and cheese samples are summarized in Tables 6 and 7.

Table 6. Fatty acid composition (\%) of goat milk from different feeding technologies

\begin{tabular}{|c|c|c|c|c|c|}
\hline \multirow{2}{*}{ Fatty acids } & \multicolumn{2}{|c|}{ Indoor group $(\mathrm{n}=10)$} & \multicolumn{2}{|c|}{ Grazed group $(\mathrm{n}=10)$} & \multirow{2}{*}{$\mathrm{P}$} \\
\hline & mean & SD & mean & $\mathrm{SD}$ & \\
\hline C6:0 & 1.31 & 0.08 & 1.97 & 0.25 & $* * *$ \\
\hline $\mathrm{C} 8: 0$ & 2.06 & 0.15 & 2.45 & 0.14 & $* * *$ \\
\hline C10:0 & 9.60 & 1.09 & 10.04 & 0.75 & NS \\
\hline $\mathrm{C} 12: 0$ & 5.18 & 1.65 & 4.35 & 0.60 & NS \\
\hline $\mathrm{C} 14: 0$ & 12.21 & 1.40 & 12.44 & 1.44 & NS \\
\hline C14:1 & 0.20 & 0.07 & 0.19 & 0.07 & NS \\
\hline C16:0 & 32.49 & 3.27 & 33.84 & 3.21 & NS \\
\hline C16:1 & 0.84 & 0.19 & 0.59 & 0.10 & $* *$ \\
\hline C18:0 & 7.85 & 1.49 & 6.49 & 1.50 & NS \\
\hline C18:1n-9c & 17.93 & 2.26 & 18.25 & 3.82 & NS \\
\hline CLA & 0.59 & 0.12 & 0.77 & 0.13 & $* * *$ \\
\hline c9t11CLA & 0.49 & 0.10 & 0.66 & 0.13 & $*$ \\
\hline$t 10 c 12 \mathrm{CLA}$ & 0.10 & 0.02 & 0.11 & 0.03 & NS \\
\hline C18:2n-6 & 2.87 & 0.54 & 2.02 & 0.34 & $* *$ \\
\hline $\mathrm{C} 18: 3 n-3$ & 0.38 & 0.05 & 0.49 & 0.11 & $* *$ \\
\hline C20:4n-6 & 0.24 & 0.06 & 0.26 & 0.07 & NS \\
\hline$C 20: 5 n-3$ & 0.03 & 0.01 & 0.07 & 0.01 & $*$ \\
\hline C22:6n-3 & 0.02 & 0.01 & 0.04 & 0.01 & $*$ \\
\hline SFA & 74.46 & 2.74 & 74.80 & 4.21 & NS \\
\hline MUFA & 21.73 & 2.44 & 19.03 & 3.87 & NS \\
\hline PUFA & 3.81 & 1.87 & 6.17 & 0.59 & $* *$ \\
\hline$n-6$ & 3.13 & 0.55 & 2.30 & 0.33 & $* * *$ \\
\hline$n-3$ & 0.52 & 0.07 & 0.69 & 0.13 & $* *$ \\
\hline n-6/n-3 & 6.10 & 1.16 & 3.44 & 0.63 & $* * *$ \\
\hline
\end{tabular}

Grazing significantly increased the concentrations of caproic $\left(\mathrm{C}_{6: 0}\right)$, caprylic $\left(\mathrm{C}_{8: 0}\right)$, total conjugated linoleic, c9t11 conjugated linoleic $\left(\mathrm{C}_{18: 2}\right), \alpha$-linolenic $\left(\mathrm{C}_{18: 3}\right)$, eicosapentaenoic $\left(\mathrm{C}_{20: 5}\right)$, docosahexaenoic $\left(\mathrm{C}_{22: 6}\right)$, total polyunsaturated and $\mathrm{n}-3$ fatty acids in milk. The palmitoleic $\left(\mathrm{C}_{16: 1}\right)$, linoleic $\left(\mathrm{C}_{18: 2}\right), \mathrm{n}-6$ fatty acids and $n-6 / n-3$ ratio were lower in the milk from grazed goats than from the indoors group. 
Table 7. Fatty acid composition (\%) of goat cheese from different feeding technologies

\begin{tabular}{|c|c|c|c|c|c|}
\hline \multirow{2}{*}{ Fatty acids } & \multicolumn{2}{|c|}{ Indoor group $(n=3)$} & \multicolumn{2}{|c|}{ Grazed group $(n=3)$} & \multirow{2}{*}{ P } \\
\hline & mean & $\mathrm{SD}$ & mean & SD & \\
\hline C6:0 & 1.44 & 0.01 & 2.32 & 0.03 & $* * *$ \\
\hline C8:0 & 1.28 & 0.11 & 2.20 & 0.02 & $* * *$ \\
\hline C10:0 & 7.28 & 0.63 & 9.10 & 0.50 & $*$ \\
\hline C12:0 & 4.19 & 0.13 & 3.42 & 0.82 & NS \\
\hline C14:0 & 11.93 & 1.33 & 10.05 & 1.53 & NS \\
\hline C14:1 & 0.19 & 0.02 & 0.13 & 0.04 & NS \\
\hline $\mathrm{C} 16: 0$ & 31.46 & 1.40 & 27.57 & 1.72 & NS \\
\hline C16:1 & 0.65 & 0.02 & 0.46 & 0.10 & $*$ \\
\hline C18:0 & 8.22 & 0.22 & 7.46 & 0.45 & NS \\
\hline C18:1n-9c & 22.03 & 2.34 & 23.74 & 2.48 & NS \\
\hline CLA & 0.52 & 0.06 & 0.84 & 0.11 & $* *$ \\
\hline$c 9 t 11 \mathrm{CLA}$ & 0.43 & 0.05 & 0.71 & 0.09 & $* *$ \\
\hline$t 10 c 12 \mathrm{CLA}$ & 0.09 & 0.01 & 0.13 & 0.02 & * \\
\hline C18:2n-6 & 2.48 & 0.14 & 2.46 & 0.09 & NS \\
\hline$C 18: 3 n-3$ & 0.41 & 0.03 & 0.81 & 0.15 & $* *$ \\
\hline$C 20: 4 n-6$ & 0.28 & 0.04 & 0.19 & 0.04 & $*$ \\
\hline$C 20: 5 n-3$ & 0.05 & 0.00 & 0.07 & 0.01 & $*$ \\
\hline C22:6n-3 & 0.04 & 0.01 & 0.07 & 0.01 & $*$ \\
\hline SFA & 73.42 & 2.74 & 71.44 & 3.64 & NS \\
\hline MUFA & 22.87 & 2.37 & 24.32 & 2.33 & NS \\
\hline PUFA & 3.71 & 0.21 & 4.24 & 0.05 & $*$ \\
\hline$n-6$ & 2.76 & 0.17 & 2.65 & 0.06 & NS \\
\hline$n-3$ & 0.64 & 0.02 & 1.07 & 0.16 & $* *$ \\
\hline$n-6 / n-3$ & 4.29 & 0.24 & 2.51 & 0.40 & $* *$ \\
\hline
\end{tabular}

NS - non significantly difference; ${ }^{*}-\mathrm{P}<0.05 ; * *: \mathrm{P}<0.01 ; * * *-\mathrm{P}<0.001$ - significant differences between two groups; SFA - saturated fatty acids; MUFA - monounsaturated fatty acids; PUFA polyunsaturated fatty acids

The fatty acid profiles in our study are similar to the findings of other authors in milk studies (Park et al., 2007).

Concentrations of caproic $\left(\mathrm{C}_{6: 0}\right)$, caprylic $\left(\mathrm{C}_{8: 0}\right)$, capric $\left(\mathrm{C}_{10: 0}\right)$, total conjugated linoleic, c9t11 conjugated linoleic $\left(\mathrm{C}_{18: 2}\right), \alpha$-linolenic $\left(\mathrm{C}_{18: 3}\right)$, eicosapentaenoic $\left(\mathrm{C}_{20: 5}\right)$, docosahexaenoic $\left(\mathrm{C}_{22: 6}\right)$, total polyunsaturated and $\mathrm{n}-3$ fatty acids were higher in the cheese from grazed goats than in that from animals kept indoors. The palmitoleic $\left(\mathrm{C}_{16: 1}\right)$, linoleic $\left(\mathrm{C}_{18: 2}\right), \mathrm{n}-6$ and $\mathrm{n}-6 / \mathrm{n}-3$ ratios were lower in the cheese from grazed goats than from non-grazed goats.

The proportion of SFA and MUFA was similar in the two feeding systems. Grazing significantly increased the proportion of long-chain polyunsaturated n-3 
fatty acids, such as $\alpha$-linolenic, eicosapentaenoic and docosahexaenoic fatty acids, and decreased the n-6/n-3 fatty acids ratio in milk and cheese.

\section{DISCUSSION}

It is well known that the gross composition of goat milk is affected by many factors, such as diet, breed, parity, stage of lactation, and environmental conditions (Guo et al., 2001). Soriano et al. (2001) in Holstein cows and Soryal et al. (2004) in Alpine goat also found that pasture feeding slightly increased the milk fat, protein and solid without fat contents and decreased the lactose content. These results suggested that the milk produced by the grazed group would have a higher cheese yield.

The $c 9 t 11$ conjugated linoleic acid $\left(c 9 t 11 \mathrm{CLA}_{18: 2}\right)$ has a range of positive health properties such as anticarcinogenic and antiatherogenic effects. c9t11CLA is synthesised in the rumen by anaerobic bacteria (B. fibrisolvens) from linoleic acid. Furthermore, $c 9 t 11$ CLA can be produced in an alternative way in the mammary gland via $\Delta 9$-desaturase activity from vaccenic acid $\left(t 11 \mathrm{C}_{18: 1}\right)$. The importance of vaccenic acid lies, therefore, in its role as a precursor in the synthesis of c9t11CLA in the mammary gland (Bauman et al., 2001) and also in some human tissues (Turpeinen et al., 2002).

Another conjugated linoleic isomer is $t 10 c 12 \mathrm{CLA}$. The $c 9 t 11 \mathrm{CLA}$ content in milk and in cheese was $84 \%$. This observation corresponds with data published by Chin et al. (1992), who found that the $c 9 t 11$ CLA isomer makes up between 75 and $90 \%$ in animal and dairy products. The proportions of $c 9 t 11$ CLA and $t 10 c 12$ CLA were 82.8 and $85.4 \%$ in milk $(\mathrm{P}<0.05)$ and 83.2 and $84.2 \%$ in cheese $(\mathrm{P}>0.05)$. The $110 c 12 \mathrm{CLA}$ produced in the rumen may be the result of minor bacterial populations or the alternative biohydrogenation pathway in the rumen (Tsiplakou et al., 2006).

The water content of the grass affects microbiological fermentation and $\mathrm{pH}$ in the rumen. Rumen $\mathrm{pH}$ has an important role in maintaining a viable rumen environment suitable for $B$. fibrisolvens. It has been shown that a ruminal $\mathrm{pH}$ of 6.0 or above has a positive effect on CLA isomer production (Tsiplakou et al., 2008).

Grazing significantly increased the concentration of polyunsaturated fatty acids, such as $\alpha$-linolenic acid $(0.49 \%)$. The milk from non-grazed goats had an $\alpha$-linolenic acid content of $0.38 \%$. Sampelayo et al. (1998) found the $\alpha$-linolenic acid content to be $0.3 \%$ in goat milk when the animals were fed with lucerne hay. Grass contains a low level of fat, but $\alpha$-linolenic acid accounted for $40 \%$ of total fatty acids. Another author showed that $50-75 \%$ of the total fat is $n-3$ fatty acids 
in grass (Cabiddu et al., 2005). Increasing the supply of n-3 fatty acids in the diet is one of the most important ways of improving the $n-3$ content of ruminant milk. Grass is a dietary source of n-3 fatty acids like linseed (Brzóska, 2006) and rapeseed (Kudrna and Marounek, 2006) oils in ruminant feeds. The distribution of n- 6 and n-3 fatty acids was much better in the grazed goat group. The values of the $\alpha$-linolenic, eicosapentaenoic and docosahexaenoic acids were higher in the milk and cheese from grazed animals than in those of the goat group kept indoors. $\alpha$-linolenic acid is the precursor of such n-3 PUFAs as eicosapentaenoic acid (EPA) $\left(\mathrm{C}_{20: 5} \mathrm{n}-3\right)$ and docosahexaenoic acid (DHA) $\left(\mathrm{C}_{22: 6} \mathrm{n}-3\right)$, which efficiently prevent coronary heart disease (CHD).

The ratio of PUFA n-3/n-6 is an index commonly used to assess the nutritional value of fats. By the estimation of Wood et al. (2003) the optimal value of the $\mathrm{n}-6 / \mathrm{n}-3$ ratio should be $4: 1$ or less. The $n-6 / n-3$ ratios were 3.44 and 2.51 in the milk and cheese from the grazed goats, respectively. Some authors have shown that the cheese from grazed animals had better quality than that of cattle and goats fed indoors (Schlichtherle-Cerny et al., 2004; Galina et al., 2007). The low ratio of $n-6 / n-3$ in the experimental goats is in line with the new recommendations for human nutrition.

The effort to increase the $c 9 t 11$ CLA content and change the fatty acid profile in milk by dietary manipulation may provide functional food for human consumption. Although the c9t1lCLA content in dairy products is affected by many factors, animal feeding strategies and specific diets with high supplements of PUFA can be effective in the enriching milk of dairy species (Luna et al., 2005).

\section{CONCLUSIONS}

Grazing considerably increases the fat, protein and total solids contents in goat milk. A significant increase of total c9t11CLA, $\alpha$-linolenic, eicosapentaenoic and docosahexaenoic fatty acids in milk and cheese can also be achieved by grazing. Grass feeding significantly reduces the n-6/n-3 ratio in milk and cheese. Consumer benefit from the nutraceutical effects of milk and cheese produced by grazed animals is lies in particular in the decrease of the n-6/n-3 ratio and the high conjugated linoleic acid ( $c 9 t 11)$ content, which improve human health by having a beneficial effect on the cardiovascular system.

In the hot summer months when the pastures are dry, animals need to be provided with some supplementary feed, which basically means a hay-based diet. During this period the decrease of the $c 9 t 11$ CLA and n-3 fatty acid contents in milk can be observed. Therefore, further research is needed to ascertain the effect of green forage supplementation (such as green maize) on the CLA isomer and n-3 
fatty acid compositions of milk and cheese.

\section{REFERENCES}

AOAC, 1990. Association of Official Analytical Chemists, Official Methods of Analysis. 15 $5^{\text {th }}$ Edition. Arlington, VA

Belury M.A., 1995. Conjugated dienic linoleate: a polyunsaturated fatty acid with unique chemoprotective properties. Nutr. Rev. 53, 83-89

Brzóska F., 2006. Effect of fatty acid calcium salts from linseed oil on the yield and n-3 fatty acid content of milk and on blood plasma parameters of cows. J. Anim. Feed Sci. 15, 347-360

Cabiddu A., Decandia M., Addis M., Piredda G., Pirisi A., Molle G., 2005. Managing Mediterranian pastures in order to enhance the level of beneficial fatty acids in sheep milk. Small Ruminant Res. 59, 169-180

Chin S.F., Liu W., Storkson J.M., Ha Y.L., Pariza M.W., 1992. Dietary sources of conjugated dienoic isomers of linoleic acid, a newly recognized class of anticarcinogens. J. Food Comp. Anal. 5, $185-197$

Cook M.E., Miller C.C., Park Y., Pariza P., 1993. Immune modulation by altered nutrient metabolism: nutritional control of immune-induced growth depression. Poultry Sci. 72, 1301-1305

Czauderna M., Kowalczyk J., Żebrowska T., Michalski J.P., Wąsowska I., 2007. Response of milk fatty acid profile to various protein levels in goat diets with similar fatty acid content. J. Anim. Feed. Sci. 16, Suppl. 2, 548-553

Enser M., Hallet K., Hewett K., Fursey G.A.J., Wood J.D., Harrington G., 1998. Fatty acid content and composition of UK beef and lamb muscle in relation to production system and implications for human nutrition. Meat Sci. 49, 329-341

Galina M.A., Osnaya F., Cuchillo H.M., Haenlein G.F.W., 2007. Cheese quality from milk of grazing or indoor fed Zebu cows and Alpine crossbred goats. Small Ruminant Res. 71, 264-272

Guo M.R., Dixon P.H., Park Y.W., Gilmore J.A., Kindstedt P.S., 2001. Seasonal changes in the chemical composition of commingled goat milk. J. Dairy Sci. 84, Suppl. E, E79-E83

Hasler C., 2000. The changing face of functional foods. J. Amer. Coll. Nutr. 19, 499-506

Hungarian Feed Codex, 1990. Vol. 2. Chapters 5.1, 6.1, 7.1, 8.1, 10.1 (in Hungarian)

Kudrna V., Marounek M., 2006. The influence of feeding rapeseed cake and extruded soyabean on the performance of lactating cows and the fatty acid pattern of milk. J. Anim. Feed Sci. 15, 361-369

Luna P., Fontecha J., Juarez M., de la Fuente M.A., 2005. Changes in the milk and cheese fat composition of ewes fed commercial supplements containing linseed with special reference to the CLA content and isomer composition. Lipids 40, 445-453

Nicolasi R.J., Rogers E.J., Kritchevski D., Scimeca J.A., Huth P.J., 1997. Dietary conjugated linoleic acid reduces plasma lipoproteins and early aortic atherogenesis in hypercholesterolemic hamsters. Artery 22, 266-277

Park Y.W., Juarez M., Ramos M., Haenlein G.F.W., 2007. Physico-chemical characteristics of goat and sheep milk. Small Ruminant Res. 68, 88-113

Sampelayo, M.R.S., Perez, L., Boza, J., Amigo, L., 1998. Forage of different physical forms in the diets of lactating Granadina goats: nutrient digestibility and milk production and composition. J. Dairy Sci. 81, 492-498

Schlichtherle-Cerny M.I., Imhof G., Fernandez-Garcia E., Bosset J.O., 2004. Changes in terpene composition from pasture to cheese. In: Proceedings Cheese Art 2004. $6^{\text {th }}$ International Meeting Mountain Cheese, Raguza (Italy), pp. 1-14 
Soriano F.D., Polan C.E., Miller C.N., 2001. Supplementing pasture to lacting Holsteins fed a total mixed ration diet. J. Dairy Sci. 84, 2460-2468

Soryal K.A., Zeng S.S., Min B.R., Hart S.P., Beyene F.A., 2004. Effect of feeding systems on composition of goat milk and yield of Domiati cheese. Small Ruminant Res. 54, 121-129

Tsiplakou E., Kominakis A., Zervas G., 2008. The interaction between breed and diet on CLA and fatty acids content of milk fat of four sheep breeds kept indoors or at grass. Small Ruminant Res. 74, 179-187

Tsiplakou E., Mountzouris K.C., Zervas G., 2006. Concentration of conjugated linoleic acid in grazing sheep and goat milk fat. Livest. Sci. 103, 74-84

Turpeinen A.M., Mutanen M., Aro A., Salminen I., Basu S., Palmquist D.L., Griinari J.M., 2002. Bioconversion of vaccenic acid to conjugated linoleic acid in humans. Amer. J. Clin. Nutr. 76, 504-510

Williams C.M., 2000. Dietary fatty acids and human health. Ann. Zootech. 49, 165-180

Wood J.D., Richardson R.I., Nute G.R., Fisher A.V., Campo M.M., Kasapidou E., Sheard P.R., Enser M., 2003. Effects of fatty acids on meat quality: a review. Meat Sci. 66, 21-32 